\title{
Original Research \\ Pharmaceutical and chemical pediatric poisoning in Kuwait: a retrospective survey
}

\author{
Eman A. ABAHUSSAIN, Douglas E. BALL. \\ Received (first version): 18-Aug-2009 Accepted: 18-Nov-2009
}

\begin{abstract}
${ }^{\star}$
Past studies of pediatric poisoning in Kuwait have suggested differences at hospital level which could impact on the implementation of public health interventions. The objective was to compare pediatric poisoning admissions at general hospitals in Kuwait.

Methods: Retrospective survey of all pediatric poisoning cases at the six general hospitals from January 2004 to December 2005. Case data were documented using ICD-10 criteria and the poisoning severity score. Aggregated data was also obtained from five private hospitals.

Results: 978 children were admitted in public hospitals over 2004 and 2005 (no fatalities) being $1.8 \%$ and $1.6 \%$ of all pediatric admissions (private hospitals admitted 293 cases). The majority of the poisoning cases came from Jahra hospital (>35\%), the median age was $2.3 \mathrm{yrs}, 93 \%$ of cases were under 6 yrs old and $71 \%$ were Kuwaiti. Two thirds of cases involved pharmaceuticals although this varied between hospitals with a tendency for more severe cases with chemical poisoning $(p=0.011)$. Kerosene was an important problem at Jahra hospital (34.7\% of chemical exposures). Non-opioid analgesics constituted $22.3 \%$ of medication exposures with hormones and drugs affecting the autonomic nervous system also common with some difference in pattern between institutions.

Conclusion: Case demographics do not vary significantly between the hospitals but there are differences in the nature of toxic agents to which children are exposed suggesting that preventive and educational programs could be targeted to specific areas for maximal effect particularly with regard to household chemical and kerosene exposures.
\end{abstract}

Keywords: Infant. Child. Poisons. Accidents, Home. Kuwait.

\section{ENVENENAMIENTO PEDIÁTRICO POR PRODUCTOS QUÍMICOS Y MEDICAMENTOS EN KUWAIT: ESTUDIO RETROSPECTIVO}

\section{RESUMEN}

Anteriores estudios de envenenamiento pediátrico han sugerido diferencias a nivel hospitalario que podrían tener impacto en la implantación de intervenciones de salud pública. El objetico fue comparar los ingresos de envenenamientos pediátricos en hospitales generales de Kuwait. Métodos: Estudio retrospectivo de todos los casos de envenenamiento pediátrico en seis hospitales de enero 2004 a diciembre 2005. Los datos de los casos se documentaron utilizando los criterios CIE10 y las puntuaciones de gravedad. Se obtuvieron también datos agregados de cinco hospitales privados.

Resultados: 978 niños ingresaron en hospitales públicos durante 2004 y 2005 (sin muertes) siendo el 1,8\% y el 1,6\% de todas lis ingresos pediátricos (los hospitales privados ingresaron 293 casos). Na mayoría de los casos de envenenamiento vinieron del hospital de Jahra (>35\%), la mediana de edad fue de 2,3 años, el $93 \%$ de los casos fueron d niños de menos e 6 años y el $71 \%$ eran kuwaitíes. Dos tercios de los casos involucraron medicamentos, aunque esto varió entre hospitales con una tendencia hacia casos más graves con los envenenamientos por químicos $(\mathrm{p}=0,011)$. El keroseno fue un problema importante en el hospital de Jahra (34,7\% de las exposiciones a químicos). Los analgésicos no opioides constituyeron el 22,3\% de las exposiciones a medicamentos con las hormonas y los medicamentos que afectan al sistema nervioso autónomo también frecuentes con algunas diferencias en el patrón entre instituciones. Conclusión: La demografía de los casos no varía significativamente entre los hospitales pero hay diferencias en la naturaleza de los agentes tóxicos a los que se exponen los niños sugiriendo que los programas preventivos y educativos podrían dirigirse a áreas especificas para maximizar los efectos, particularmente con respecto a las exposiciones a productos químicos almacenados en casa y a keroseno.

Palabras clave: Niños. Jóvenes. Venenos. Accidentes caseros. Kuwait.

*Eman A. ABAHUSSAIN. PhD. Clinical lecturer, Department of Pharmacy Practice, Faculty of Pharmacy, Kuwait University. Kwait (Kwait).

Douglas E. BALL. PhD. Pharmaceutical consultant. Manila (Philippines). 


\section{INTRODUCTION}

Poisoning is an important global health problem, with the bulk of accidental exposures occurring in children especially those less than 5 years of age. ${ }^{1}$ An increasing range and availability of medicines and chemicals that are commonly used worldwide makes for easy exposure and, while the implementation of child-proof containers and poison control centers have had dramatic effects on pediatric poisoning in some developed nations, poisoning remains common especially in developing countries. $^{2-4}$

In Kuwait, the pediatric poisoning admissions due to drugs and biological substances as a proportion of all ages range from $35 \%$ to $50 \%$ over the period 2000 to 2005 according to official Ministry of Health data (Figure 1) with an apparent increase in the latter two years after an earlier decline. ${ }^{5-9}$ This data is complemented by prior retrospective studies that have been performed in Kuwait to describe the pattern of pediatric poisoning admissions. Three studies from the 1980s reported pediatric poisoning admission rates of $3.7,2.0$ and $3.9 \%$ with medicine exposures predominating (57-68\% of cases) at Amiri $^{10}$, Sabah ${ }^{11}$ and Farwaniya $^{12}$ hospitals respectively while a more recent survey at Jahra hospital reported an admission rate of $1.6 \%$ with $56 \%$ of cases involving household chemicals, particularly kerosene. ${ }^{13}$ The recommendations from these four previous papers can be summarized into three points: continuous poisoning awareness educational programs in the community are required, child-resistant containers should be introduced and routine hospital admission for childhood poisoning is unnecessary since most cases can be treated in the casualty observation room. However, in spite of the public health recommendations arising from these studies, little has been done to address childhood poisoning in Kuwait which has no current functional poison control centre.

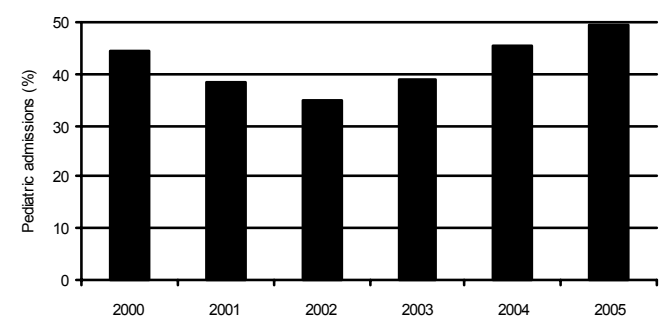

Figure 1. The contribution of pediatric cases to poisoning admissions due to drugs and biological substances at hospitals in Kuwait from 2000 to $2005 .^{a b}$

${ }^{a}$ Citations 5-9.

${ }^{b}$ Includes food, insect poisonings

From these previous surveys it would appear that there may be differences in pediatric poisoning admission rates and patterns of poisoning between hospitals in Kuwait. However, the fact that each survey only covered one hospital and they were conducted in different years by various groups makes such historical data unreliable for comparisons. Therefore, the objective of this research was to describe pediatric poisoning admissions to hospitals in Kuwait due to drugs and chemicals over the two years 2004 and 2005, comparing the rates and patterns of poisoning across the major public hospitals.

\section{METHODS}

A descriptive retrospective survey was undertaken using data between January 2004 through December 2005 at six main government general hospitals in Kuwait (Jahra, Mubarak Al-Kabir, Farwaniya, Amiri, Adan and Sabah hospitals). All cases of chemical and pharmaceutical poisoning recorded as having occurred in children of age 12 years and below were included in this study. The definition of medicine and chemical was as per International Classification of Disease (ICD)-10 classification, thus alcohol poisoning was included as a chemical exposure (4 cases). Cases of food poisoning or insect envenomation or other exposures were excluded. As a policy in Kuwait at government hospitals, any child brought to the Emergency Department (Casualty) with suspected poisoning is admitted to the ward for treatment and observation at least one day irrespective of their clinical presentation or type of poisoning. Case files were identified either from records held in the statistical department in the Ministry of Health or from hospital admission/discharge records or pediatric ward records according to hospital procedures.

Ethical clearance was received from the Studies and Research Unit at the Kuwait Institute for Medical Specialization (KIMS), Ministry of Health and from each hospital to access the patient files. All information taken from patient files was treated confidentially and no patient identifying information was captured.

Information was recorded on a standardized data collection form by a qualified pharmacist. This included patient demographic data (age, gender, nationality), exposure time and place, the time since exposure to presentation, the treatment received, the suspected substance(s), the route and time of ingestion or exposure, clinical presentation, medical management prior to the hospital and after reaching the Emergency Department and finally any complications arising and the duration of stay in hospital. Clinical presentation was also graded using the standardized Poisoning Severity Score (PSS) comprising 0 (none), 1 (minor), 2 (moderate), 3 (severe) and 4 (fatal) ${ }^{14}$ using the information available in the records. Cases were classified by both investigators as being either due to medicines or chemicals (including kerosene, detergents, paints, pesticides). The toxic agent was classified using the ICD-10 codes.

To supplement the information from government hospitals, record departments at the five main private hospitals were approached to provide data on the number of pediatric poisoning cases 
(including all forms of intoxication such as food poisoning, insect/animal envenomation). It was not possible to obtain more detailed information from this sector which contributes about one-quarter of health care expenditures in the emirate.

Data was analyzed with SPSS statistical software (SPSS Inc, ver. 15) using chi-squared test to compare proportions.

\section{RESULTS}

A total of 978 children were admitted to government hospitals for poisoning in the two year period 2004 2005 with no reported fatalities. These represented $1.8 \%$ and $1.6 \%$ of all pediatric admissions (Table 1 ). The majority of the poisoning cases came from Jahra hospital (>35\%) followed by Adan hospital and Mubarak Al-Kabir hospitals (Table 2). The median age was 2.5 yrs in 2004 and 2.3 yrs in 2005 (overall $2.3 \mathrm{yrs}$ ). $60 \%$ were from the $1-2$ year age group and $93 \%$ of cases were children less than five years of age (Table 2). The majority of cases $(71 \%)$ were Kuwaiti and $53 \%$ were male. Since there were no significant differences in patient demographics or pattern of poisoning between the two years, data was combined for further analysis. Data from the five private hospitals showed 147 admissions in 2004 and 146 in 2005. This indicates that about one quarter of pediatric poisoning cases present at private hospitals. This data is not considered further in the analysis.

\begin{tabular}{|c|c|c|c|c|}
\hline \multirow[b]{2}{*}{ Hospital } & \multicolumn{2}{|c|}{2004} & \multicolumn{2}{|c|}{2005} \\
\hline & $\begin{array}{l}\text { No. of } \\
\text { cases }^{a}\end{array}$ & $\begin{array}{l}\text { Admission } \\
\text { rate }(\%)\end{array}$ & $\begin{array}{l}\text { No. of } \\
\text { cases } \\
a\end{array}$ & $\begin{array}{c}\text { Admission } \\
\text { rate }(\%)\end{array}$ \\
\hline Jahra & 181 & 3.6 & 182 & 3.2 \\
\hline Sabah & 25 & 0.4 & 23 & 0.4 \\
\hline Mubarak & 115 & 2.8 & 53 & 1.1 \\
\hline Amiri & 27 & 1.3 & 15 & 0.6 \\
\hline Adan & 100 & 1.7 & 128 & 2.1 \\
\hline Farwaniya & 59 & 1.3 & 67 & 1.5 \\
\hline Total & 507 & 1.8 & 468 & 1.6 \\
\hline
\end{tabular}

Table 3 illustrates in more details the differences in the demographic characteristics of the poisoned children referred to the six general hospitals over the two years. The median age ranged from 2.2 to 2.5 years. Although there was some variability in age and gender distribution these were not statistically significant. Nationality of admissions did vary significantly among the hospitals with the proportion of Kuwaiti patients varying from $82 \%$ at Adan hospital to $59 \%$ at Mubarak Al-Kabir hospital.

Of the admissions, $64.6 \%$ of cases were associated with medicines and the remainder with chemical agents with $70 \%$ of patients Kuwaiti citizens in each case (Table 4). Boys tended to be involved in chemical exposures more than girls $(57.5 \%$ vs. $51.2 \% ; p=0.06)$ and a higher proportion of children 3 years and under were involved in chemical exposures $(83.9 \%$ vs. $72.3 \%$; $p<0.001)$. While more than $90 \%$ of cases had a presenting Poisoning Severity Score of 0 or 1 (none or minor symptoms) with both types of exposure, there was a tendency for more severe cases with chemical poisoning $(p=0.011)$. About $65 \%$ of cases occurred in the evening (between 6 p.m. and 6 a.m.) in both cases and more than $90 \%$ of cases arrived at the hospital within 2 hours of the exposure. There was some variability between hospitals in the same parameters although the incomplete nature of the medical records preventing solid conclusions. However, Jahra, Sabah and Amiri hospitals tended to have a higher proportion of cases admitted with some symptoms of poisoning present (Table 5).

Table 2. Demographic and exposure characteristics of the poisoning cases referred to the six general hospital in the two years (2004 and 2005) $(\mathrm{N}=978)$

\begin{tabular}{|c|c|c|c|}
\hline Characteristics & $\begin{array}{l}2004 \\
\mathrm{n}(\%)\end{array}$ & $\begin{array}{l}2005 \\
\text { n (\%) }\end{array}$ & $\begin{array}{l}\text { Total } \\
\mathrm{n}(\%)\end{array}$ \\
\hline \multicolumn{4}{|l|}{ Age group } \\
\hline$<1 \mathrm{yr}$ & $16(3.2)$ & $21(4.5)$ & $37(3.8)$ \\
\hline $1-2 y r$ & $293(58.4)$ & $287(61.4)$ & $582(60.4)$ \\
\hline $3-5 y r$ & $150(29.9)$ & $129(27.6)$ & $280(29.1)$ \\
\hline $6-12 \mathrm{yr}$ & $43(8.6)$ & $30(6.4)$ & $64(6.6)$ \\
\hline \multicolumn{4}{|l|}{ Gender } \\
\hline Male & $263(52.5)$ & $251(54.2)$ & $516(53.4)$ \\
\hline \multicolumn{4}{|l|}{ Nationality } \\
\hline Kuwaiti & $342(69.7)$ & $329(72.1)$ & $673(70.9)$ \\
\hline \multicolumn{4}{|l|}{ Hospital } \\
\hline Jahra & $181(35.7)$ & $182(38.9)$ & $363(37.1)$ \\
\hline Sabah & $25(4.9)$ & $23(4.9)$ & $48(4.9)$ \\
\hline Mubarak & $115(22.7)$ & $53(11.3)$ & $168(17.2)$ \\
\hline Amiri & $27(5.3)$ & $15(3.2)$ & $42(4.3)$ \\
\hline Adan & $100(19.7)$ & $128(27.4)$ & $230(23.5)$ \\
\hline Farwaniya & $59(11.6)$ & $67(14.3)$ & $127(13.0)$ \\
\hline \multicolumn{4}{|l|}{ Exposure } \\
\hline Medicine & $334(66.0)$ & $294(62.8)$ & $631(64.6)$ \\
\hline Chemical & $172(34.0)$ & $174(37.2)$ & $346(35.4)$ \\
\hline
\end{tabular}

The nature of the exposures varied to some extent between the general hospitals (Table 6). Jahra (39.8\%), Sabah (45.9\%) and Amiri (47.6\%) hospitals tended to have a higher proportion of cases admitted with chemical exposures, with kerosene commonly implicated at Jahra hospital $(34.7 \%$ of chemical exposures). Pesticides, including rodenticides, accounted for almost $20 \%$ of all chemical-related admissions. In the case of medication exposures, non-opioid analgesics accounted for $22.3 \%$ and was the most common agent at all hospitals. Hormones (12.7\%) and drugs affecting the autonomic nervous system (11.3\%) were the next most common although $19.2 \%$ of medication exposures at Sabah hospital involved psychotropic drugs, and drugs acting on the respiratory system were important at Amiri hospital $(13.6 \%)$.

\section{DISCUSSION}

In this study, the overall admission rate in the six hospital in Kuwait in the years 2004 and 2005 was $1.8 \%$ and $1.6 \%$ respectively. These rates are comparable to what has been reported previously 
for Sabah ${ }^{11}$ and Jahra ${ }^{13}$ hospitals but lower than the $3.9 \%$ and $3.7 \%$ previously found at Farwaniya and Amiri hospitals respectively. ${ }^{10,12}$ The admissions rate due to accidental pediatric poisoning in Kuwait is similar to some reports from other Arabian Gulf countries $^{17,18}$ and less than has been reported in various regions of Saudi Arabia. ${ }^{19-21}$ Closer examination of the hospital-specific rates revealed that there are some local differences. Admission rates at Jahra hospital were high in both years, while Mubarak and Amiri showed significant variation from year to year. It is difficult to explain this disparity which would require examination of data over a longer time period for full assessment of whether it is simple natural variation or a result of population dynamics or other factors.
Examination of the patient demographics showed that the highest rate of poisoning was among children less than five years old, which is consistent with other studies in Kuwait and abroad. ${ }^{1,13}$ In fact, children of 1 to 2 years accounted for about $60 \%$ of cases, perhaps indicating the inquisitive nature of children once they start to walk and explore their environment. In addition, those less than 3 do not attend school and so stay at home where lack of appropriate supervision and poor storage of chemicals can result in toxic exposures. Lower admission rates for 3 to 5 years olds could also reflect parents becoming more aware of the dangers at this stage of their childrens' lives.

All hospitals showed a similar age distribution of pediatric poisoning patients although Amiri hospital had a slightly larger proportion of older children.

\begin{tabular}{|c|c|c|c|c|c|c|c|}
\hline \multirow[b]{2}{*}{ Variables } & \multicolumn{6}{|c|}{ Hospitals n (\%) (n=978) } & \multirow[b]{2}{*}{$p^{a}$} \\
\hline & $\begin{array}{c}\text { Jahra } \\
\mathrm{n}=(363)\end{array}$ & $\begin{array}{l}\text { Sabah } \\
n=(48)\end{array}$ & $\begin{array}{c}\text { Mubarak } \\
n=(168)\end{array}$ & $\begin{array}{c}\text { Amiri } \\
n=(42)\end{array}$ & $\begin{array}{c}\text { Adan } \\
\mathrm{n}=(230)\end{array}$ & $\begin{array}{c}\text { Farwaniya } \\
\mathrm{n}=(127)\end{array}$ & \\
\hline \multicolumn{8}{|l|}{ Age } \\
\hline$<1 \mathrm{yr}$ & $17(4.8)$ & $1(2.1)$ & $6(3.6)$ & $2(4.8)$ & $5(2.2)$ & $6(4.7)$ & NS \\
\hline $1-2 \mathrm{yrs}$ & $\begin{array}{c}221 \\
(61.9) \\
\end{array}$ & $27(56.3)$ & $\begin{array}{c}98 \\
(58.3) \\
\end{array}$ & $19(45.2)$ & $139(60.4)$ & 77 (60.9) & \\
\hline $3-5$ yrs & $96(26.9)$ & $14(29.2)$ & $\begin{array}{c}55 \\
(32.7)\end{array}$ & $18(42.9)$ & $64(27.8)$ & $33(26.0)$ & \\
\hline $6-12$ yrs & $23(6.4)$ & $6(12.5)$ & $9(5.4)$ & $3(7.1)$ & $22(9.6)$ & $11(8.7)$ & \\
\hline Male & $\begin{array}{c}185 \\
(51.0)\end{array}$ & $29(60.4)$ & $\begin{array}{c}79 \\
(47.9)\end{array}$ & $25(64.1)$ & $134(58.8)$ & $64(51.6)$ & NS \\
\hline Kuwaiti & $\begin{array}{c}240 \\
(67.2)\end{array}$ & $38(79.2)$ & $\begin{array}{c}97 \\
(59.1)\end{array}$ & $29(78.4)$ & $180(82.2)$ & $89(71.8)$ & $p<0.001$ \\
\hline
\end{tabular}

\begin{tabular}{|c|c|c|c|}
\hline & $\begin{array}{l}\text { Medicines } \\
(n=631)\end{array}$ & $\begin{array}{c}\text { Chemicals } \\
(n=346)\end{array}$ & $p^{*}$ \\
\hline \multicolumn{4}{|l|}{ Year of poison } \\
\hline 2004 & $334(53.2)$ & $172(49.7)$ & NS \\
\hline 2005 & $294(46.8)$ & $174(50.3)$ & \\
\hline \multicolumn{4}{|l|}{ Gender } \\
\hline Male & $320(51.2)$ & $196(57.5)$ & 0.06 \\
\hline \multicolumn{4}{|l|}{ Nationality } \\
\hline Kuwaiti & $439(71.6)$ & $234(69.9)$ & NS \\
\hline \multicolumn{4}{|l|}{ Age } \\
\hline$<1$ & $20(3.2)$ & $17(4.9)$ & $<0.001$ \\
\hline $1-2$ & $346(55.3)$ & $235(68.1)$ & \\
\hline $3-5$ years & $207(33.1)$ & $73(21.2)$ & \\
\hline $6-12$ years & $53(8.5)$ & $20(5.8)$ & \\
\hline \multicolumn{4}{|l|}{ Severity of symptoms } \\
\hline None/mild & $614(97.6)$ & $327(94.5)$ & 0.011 \\
\hline Moderate/severe & $15(2.4)$ & $19(5.5)$ & \\
\hline \multicolumn{4}{|c|}{ Time from exposure to presentation } \\
\hline $\begin{array}{l}\text { Unknown / not } \\
\text { reported }\end{array}$ & $287(45.8)$ & $185(53.6)$ & $<0.001$ \\
\hline$<1 \mathrm{hr}$ & $112(17.9)$ & $86(24.9)$ & \\
\hline $1-2 \mathrm{hrs}$ & $168(26.8)$ & $60(17.4)$ & \\
\hline$>2 \mathrm{hrs}$ & $60(9.6)$ & $14(4.1)$ & \\
\hline \multicolumn{4}{|c|}{$\begin{array}{l}\text { Chi-squared test was used to compare parameters across } \\
\text { medicines and chemicals. } \\
\text { Note: Some numbers do not add to exactly the total due to } \\
\text { missing data for a few cases }\end{array}$} \\
\hline
\end{tabular}

Nationally, about $70 \%$ of patients were Kuwaiti. This contrasts with a national population which is about one-third citizens with the remainder expatriate workers who may have resided in Kuwait for generations or be present on short- or long-term contracts. However, local citizens are more likely to present as families with children - more than $50 \%$ of Kuwaitis are under 18yrs of age compared to about $8 \%$ for non-Kuwaitis. ${ }^{22}$ Therefore, the preponderance of Kuwaiti patients is probably reflective of the pediatric population rather than representing greater awareness of health services offered, greater opportunity in the home for children to be exposed to medicines or chemicals, a lower threshold for deciding when to take children to hospital or other reasons. There were statistically significant variations in the proportion of Kuwaiti patients between the hospitals, with Mubarak hospital having less than $60 \%$ Kuwaiti admissions. To some degree this reflects the population demographics of the surrounding governorates. Hawally governorate has a large proportion of nonKuwaiti residents (2.8:1 in 2006) which could explain the lower level of Kuwaiti patients at Mubarak Al-Kabir hospital. However, Farwaniya governorate has a greater proportion of nonKuwaitis (3.3:1 in 2006) and yet $72 \%$ of cases were Kuwaiti. While many poorer expatriate workers are unmarried or without their families, there would also appear to be other factors which influence utilization of health services following potential toxic exposure between the two groups. 


\begin{tabular}{|c|c|c|c|c|c|c|c|}
\hline & \multicolumn{6}{|c|}{ Hospitals n (\%) } & \multirow[b]{2}{*}{$\begin{array}{c}\text { Total } \\
(n=978)\end{array}$} \\
\hline & $\begin{array}{c}\text { Jahra } \\
n=(363)\end{array}$ & $\begin{array}{l}\text { Sabah } \\
n=(48)\end{array}$ & $\begin{array}{l}\text { Mubarak } \\
n=(168)\end{array}$ & $\begin{array}{c}\text { Amiri } \\
\mathrm{n}=(42)\end{array}$ & $\begin{array}{c}\text { Adan } \\
\mathrm{n}=(230)\end{array}$ & $\begin{array}{c}\text { Farwaniya } \\
\mathrm{n}=(127)\end{array}$ & \\
\hline \multicolumn{8}{|c|}{ Time from exposure to presentation ${ }^{* a}$} \\
\hline Unknown & $100(27.6)$ & $2(4.2)$ & $88(52.4)$ & $31(73.8)$ & $148(64.6)$ & $103(83.1)$ & $477(48.8)$ \\
\hline < one hr. & $129(35.6)$ & $21(43.8)$ & $21(12.5)$ & $1(2.4)$ & $19(8.3)$ & $7(5.6)$ & $198(20.2)$ \\
\hline $1-2 \mathrm{hrs}$ & $103(28.5)$ & $18(37.5)$ & $41(24.4)$ & $5(11.9)$ & $50(21.8)$ & $11(8.9)$ & $228(23.3)$ \\
\hline$>2 \mathrm{hrs}$ & $30(8.3)$ & $7(14.6)$ & $18(10.7)$ & $5(11.9)$ & $12(5.2)$ & $3(2.4)$ & $75(7.7)$ \\
\hline \multicolumn{8}{|c|}{ Received First Aid at home ${ }^{\star a b}$} \\
\hline Yes & $23(6.3)$ & $7(14.6)$ & $17(10.1)$ & $8(19.0)$ & $3(1.3)$ & $13(10.2)$ & $71(7.3)$ \\
\hline \multicolumn{8}{|c|}{ Poisoning severity scale (signs/symptoms) ${ }^{*}$} \\
\hline None & $193(53.3)$ & $26(55.3)$ & $118(70.2)$ & $8(19.0)$ & $147(63.9)$ & $86(67.7)$ & $578(59.2)$ \\
\hline Minor & $150(41.4)$ & $21(44.7)$ & $44(26.2)$ & $33(78.6)$ & $79(34.3)$ & $37(29.1)$ & $364(37.3)$ \\
\hline $\begin{array}{l}\text { Moderate/Seve } \\
\text { re }\end{array}$ & $19(5.2)$ & $0(0.0)$ & $6(3.6)$ & $1(2.4)$ & $4(1.7)$ & $4(3.1)$ & $34(3.5)$ \\
\hline \multicolumn{8}{|l|}{ Type of poison* } \\
\hline Medicines & $218(60.2)$ & $26(54.2)$ & $124(73.8)$ & $22(52.4)$ & $152(66.1)$ & $89(70.1)$ & $346(35.4)$ \\
\hline Chemicals & $144(39.8)$ & $22(45.8)$ & $44(26.2)$ & $20(47.6)$ & $78(33.9)$ & $38(29.9)$ & $631(64.6)$ \\
\hline
\end{tabular}

\begin{tabular}{|c|c|c|c|c|c|c|c|}
\hline \multirow[b]{2}{*}{ Compound (ICD10 code) } & \multicolumn{7}{|c|}{ Proportion of cases involving class of agent $(\%)^{a}$} \\
\hline & $\begin{array}{c}\text { Jahra } \\
(\mathrm{n}=362)\end{array}$ & $\begin{array}{l}\text { Sabah } \\
(n=48)\end{array}$ & $\begin{array}{c}\text { Mubarak } \\
(n=168)\end{array}$ & $\begin{array}{c}\text { Amiri } \\
(\mathrm{n}=42)\end{array}$ & $\begin{array}{c}\text { Adan } \\
(\mathrm{n}=230)\end{array}$ & $\begin{array}{l}\text { Farwaniya } \\
(n=127)\end{array}$ & $\begin{array}{c}\text { Total } \\
(n=977)\end{array}$ \\
\hline Chemicals $(n=346)$ & 39.8 & 45.9 & 26.2 & 47.6 & 33.9 & 29.9 & 35.4 \\
\hline \multicolumn{8}{|l|}{ Of which: } \\
\hline Kerosene (n/a) & 34.7 & 27.2 & 20.5 & 20.0 & 20.5 & 18.4 & 26.6 \\
\hline Pesticides (T60) & 14.1 & 14.3 & 15.9 & 10.0 & 37.2 & 13.5 & 19.3 \\
\hline Halogen hydrocarbons (T53) & 21.8 & 19.0 & 22.7 & 40.0 & 26.9 & 27.0 & 24.6 \\
\hline Unspecified (T65) & 6.3 & 0.0 & 0.0 & 5.0 & 2.6 & 18.9 & 5.6 \\
\hline Others & 23.1 & 39.5 & 24.5 & 25.0 & 12.8 & 22.2 & 23.9 \\
\hline Medicines $(\mathrm{n}=631)$ & 60.2 & 54.2 & 73.8 & 52.4 & 66.1 & 70.1 & 64.6 \\
\hline \multicolumn{8}{|l|}{ Of which: } \\
\hline Nonopioid analgesics (T39) & 24.3 & 38.5 & 13.7 & 40.9 & 19.1 & 25.8 & 22.3 \\
\hline Hormones (T38) & 13.8 & 7.7 & 9.7 & 4.5 & 14.5 & 14.6 & 12.7 \\
\hline Autonomic NS (T44) & 7.8 & 3.8 & 16.9 & 9.1 & 14.5 & 9.0 & 11.3 \\
\hline Haematological (T45) & 7.3 & 3.8 & 9.7 & 0.0 & 7.2 & 10.1 & 7.8 \\
\hline Respiratory (T48) & 4.6 & 3.8 & 5.6 & 13.6 & 11.8 & 9.0 & 7.4 \\
\hline GIT drugs (T47) & 8.3 & 3.8 & 3.2 & 4.5 & 3.3 & 9.0 & 5.9 \\
\hline$\geq 2$ medicines $(n / a)$ & 6.4 & 0.0 & 11.3 & 9.1 & 1.3 & 4.5 & 5.7 \\
\hline Psychotropic (T43) & 4.2 & 19.2 & 2.4 & 4.5 & 9.3 & 3.3 & 5.6 \\
\hline Unspecified (T50) & 1.8 & 0.0 & 4.0 & 0.0 & 9.2 & 3.4 & 4.1 \\
\hline Others & 21.6 & 19.2 & 23.4 & 13.6 & 9.9 & 11.2 & 17.3 \\
\hline
\end{tabular}

It is noteworthy that the great majority of cases had a Poisoning Severity Score of 0 or 1 at presentation indicating no or only mild symptoms. This may be partly due to the fact that, where data was available, most cases were seen within $2 \mathrm{hrs}$ of exposure. Although a statistically significant difference was evident between hospitals in the time from exposure to presentation, a substantial number of records did not contain this information so the data should be interpreted with caution. Chemical exposures were more likely to show symptoms, which one would expect in this short time frame given the nature of the toxic agents. This was also reflected in the fact that those hospitals with a greater case load of chemical exposures (Jahra, Sabah, Amiri) tended to have a higher proportion of cases admitted with some symptoms of poisoning. Previous studies on pediatric poisoning in Kuwait have argued against the need for routine hospital admission which is supported by this data suggesting non-serious intoxications.

Sabah and Amiri hospitals had significantly fewer cases than the other general hospitals. This is probably due to their location in mainly nonresidential areas - Sabah hospital is situated in the specialist hospital complex and mostly light industrial area and Amiri hospital in the downtown area. Their locations might also be a factor in the proportion of chemical exposures seen at these hospitals.

In this study, poisoning with medicines was found to be the most common (about two thirds of 
cases) which is similar to finding from previous studies in Kuwait. ${ }^{10-13}$ Non-opioid analgesics were the main toxic agent for medicinal exposures at all hospitals except Mubarak Al-Kabir, which is line with the reports from Farwaniya hospital ${ }^{12}$ and Amiri hospitals. ${ }^{10}$ However, Akhtar and colleagues reported only $5.7 \%$ of medicinal exposures as due to analgesics at Jahra hospital during the period 1992-1996. ${ }^{13}$ It is difficult to compare these directly due to the different time periods during which prescribing patterns may have changed. The differences noted between the hospitals in the current study are of more interest.

The differences seen in the proportions of cases due to various agents at each hospital does not seem to be all due to random variation and are perhaps also to do with local factors, some of which are not immediately clear. For example, the surfeit of cases with psychotropic medication at Sabah hospital may be related to its proximity to the specialist psychiatry hospital. Jahra hospital had the greatest proportion of kerosene exposures probably due to the its use among the Bedouin families and poorer socioeconomic classes which are common in that governorate. ${ }^{13,23} 35 \%$ of chemical exposures at Jahra hospital were due to kerosene which is lower than the $54 \%$ reported by Akhtar et al. for 1992-1996. ${ }^{13}$ This difference may be influenced by differences in the two surveys the prior study used 4-and-a-half years' data and may have used a narrower definition of what constituted a chemical - or could be related to changes in lifestyle or environmental conditions. We are not aware of any public health interventions which may have led to a reduction in caseload.

Prior studies have referred to unnecessary routine hospital admissions, the need for child-resistant containers, and public education and greater implementation of poison control centers. ${ }^{10-13}$ The results of the current study reiterate these messages. The routine admission policy increases healthcare staff workload and health system costs where a shorter observation period could suffice. $^{11,12}$ The cost of treating a pediatric poisoning admission is about USD335 (local hospital data) meaning that on average USD225,000 is spent per year in Kuwait on these cases. This could be substantially reduced by only admitting serious cases with the savings used in manning a Poison Control Centre or increasing services elsewhere in addition to freeing up staff time. The reasons that the practice of routine admissions continues would need to be investigated in the light of this mounting evidence, but could relate to the Ministry of Health fearing litigation or wanting to provide the 'best care' regardless of cost.

While child-resistant medicine containers are present in most original medicine packs, repackaged medicines from government health centers continue to be dispensed in plastic envelopes which may contribute to pharmaceutical exposures. In addition, many household chemical containers have simple closures and, in the case of kerosene, may be stored in non-original containers. This leaves an onus on parents to store medicines and chemicals appropriately in the home. These factors require both policy change and repeated public education and awareness campaigns. When poisoning does occur, poison control centers have been shown to reduce unnecessary hospital admissions as well as serving as resource centers for the management of poisoning cases. Unfortunately, the Poison Information Centre in Amiri hospital was closed more than 5 years ago and at the time of writing there is no operational poison control centre in Kuwait for either health professionals or the public. In addition to the above, other potential interventions to prevent pharmaceutical poisonings in Kuwait could address dispensing policies at government health centers and implement a mechanism for safe disposal of unwanted household medicines so as to reduce the stocks of medicines kept in the home. Previous research has found that most households have unwanted or expired medicines present and that in most cases it is thrown out in the household garbage. ${ }^{24}$

Limitations of the study include that only government hospitals were surveyed and thus cases presenting at private hospitals or other health facilities will have been missed and the rate of pediatric poisoning may be higher than observed. Our data shows that three-quarters of pediatric poisoning admissions occur in public hospitals and therefore represent the majority of cases. However, the substantive nature of the private sector caseload suggests that greater attention be paid to it in future studies. The retrospective nature of the survey meant that in some cases not all the data was recorded in the medical notes. This has been highlighted where it impacts on interpretation of the results. To overcome inaccurate coding by hospital data-entry staff, case data was scrutinized and the appropriate ICD-10 code assigned by the investigators. The use of ICD-10 coding provided a uniform method of classifying exposures, but it does not provide great detail as to the exact nature of the toxic agents.

\section{CONCLUSIONS}

Accidental poisoning of children with pharmaceuticals and chemicals is an important cause of morbidity in Kuwait. Although patient demographics are similar between hospitals, the case load varies suggesting that preventive and educational programs could be targeted to specific areas for maximal effect particularly with regard to household chemical and kerosene exposures. Ongoing awareness programs for parents of young children starting as early age are important to reduce the incidence of accidental poisoning.

\section{CONFLICT OF INTEREST}

Neither of the authors have any conflicts of interests with regard to this article. 


\section{References}

1. Eldridge DL, Van Eyk J, Kornegay C. Pediatric toxicology. Emerg Med Clin North Am. 2007;25:283-308.

2. Lawson GR, Craft AW, Jackson RH. Changing pattern of poisoning in children. BMJ. 1983;287:15.

3. Walton WW. An evaluation of the Poison Prevention Packaging Act. Pediatrics 1982;69:363-370.

4. WHO. The world health report. WHO, Geneva, 2000.

5. State of Kuwait. Health of Kuwait. Statistics Department, Ministry of Health, 2001.

6. State of Kuwait. Health of Kuwait. Statistics Department, Ministry of Health, 2002.

7. State of Kuwait. Health of Kuwait. Statistics Department, Ministry of Health, 2003.

8. State of Kuwait. Health of Kuwait. Statistics Department, Ministry of Health, 2004.

9. State of Kuwait. Health of Kuwait. Statistics Department, Ministry of Health, 2005.

10. Falaki NN, Fernando NP. Acute poisoning in children one year, one hospital experience. J Kuwait Med Assoc. 1986;20:3-11.

11. Issa ARA, Reavey PC, Al-Rashied AA. Acute poisoning in a children's hospital. J Kuwait Med Assoc. 1987;21:276-279.

12. Metwalli AA, Ismail AM. Accidental poisoning in children- the problem of drug poisoning - A study in Farwaniya hospital, Kuwait. J Kuwait Med Assoc. 1988;22:249-254.

13. Akhtar S, Raj RG, A-Anezi F. Risk factors in acute poisoning in children- A retrospective study. Kuwait Med J. 2006;38:33-36.

14. Persson HE, Sjoberg GK, Haines JA, Pronczuk de Garbino J. Poisoning severity score. J Toxicol Clin Toxicol. 1998;36:205-213.

15. WHO. The Work of WHO in the Eastern Mediterranean Region. Annual Report of the Regional Director 1 January - 31 December 2004. WHO/EMRO, Cairo, 2004.

16. WHO. The Work of WHO in the Eastern Mediterranean Region. Annual Report of the Regional Director 1 January - 31 December 2005. WHO/EMRO, Cairo, 2005.

17. Izuora G.Ike, Adeoye A. A seven- year review of accidental poisoning in children at a military hospital in Hafr Al Batin, Saudi Arabia. Ann Saudi Med. 2001;21:13-15.

18. Al-Hifzi I, Kumar P, Talol W. Hospitalisation due to acute poisoning in children-Tabuk experience. J Fam Comm Med. 1995;2:28-30.

19. El-Mouzan M, Elageb A, Ali NK. Accidental poisoning of children in the Eastern Province. Saudi Med J. 1986;7:231-236.

20. Mahdi AH, Taha SA, Al-Rifai MR. Epidemiology of accidental home poisoning in Riyadh (Saudi Arabia). J Epidemiol Community Health. 1983;37(4):291-295.

21. Al-Hazmi A. Patterns of accidental poisoning in children in Jeddah, Saudi Arabia. Ann Saudi Med 1998; 18: 457-459.

22. State of Kuwait. Report number 28 of the census. Ministry of Planning, Kuwait, Sep. 2006.

23. Shah NM, Shah MA, Radovanovic Z. Towards defining sociodemographic inequalities that may affect health in Kuwait. Med Prin Pract. 1998;7:33-46.

24. Abahussain EA, Ball DE. Disposal of unwanted medicines from households in Kuwait. Pharm World Sci. 2007;29:368373. 